\title{
It's not just an open or shut case
}

\author{
Donald D. Glower, MD
}

\author{
From the Duke University Medical Center, Durham, NC. \\ Disclosures: Author has nothing to disclose with regard to commercial support. \\ Received for publication March 11, 2018; accepted for publication March 19, 2018; available ahead of print April \\ $11,2018$. \\ Address for reprints: Donald D. Glower, MD, Duke University Medical Center, Durham, NC 27710 (E-mail: \\ Glowe001@mc.duke.edu). \\ J Thorac Cardiovasc Surg 2018; 156:143 \\ $0022-5223 / \$ 36.00$ \\ Copyright (c) 2018 by The American Association for Thoracic Surgery \\ https://doi.org/10.1016/j.jtcvs.2018.03.053
}

In a series of 26 patients from several institutions, Praz and colleagues $^{1}$ show that use of a transcatheter device is not exclusively an open or shut case. In other words, the transcatheter devices designed to be inserted percutaneously in a closed heart fashion can also be used in an open fashion on cardiopulmonary bypass. This report is relatively new as a successful early series using transcatheter aortic valve prostheses readily available on the market to replace the mitral valve in patients who are otherwise poor candidates for standard mitral prostheses.

Other open applications of transcatheter technology do exist in the literature. For example, the growing numbers of sutureless aortic valve devices are arguably transcatheter aortic valve devices modified to be inserted in an open fashion on pump. Case reports also exist for using transcatheter devices to perform open closure of ventricular septal defects $^{2,3}$ that are not easily accessible in a closed fashion. Although the authors could potentially have treated these 26 patients with off-pump transapical implantation of a transcatheter valve into the mitral position, the on-pump open approach used here does have advantages. Specifically, with the open approach, one can use adjunctive open techniques such as partial valve resection and limited application of sutures to ensure undistorted valve placement without perivalvular leakage.

Although the ultimate goal might be to use transcatheter technology percutaneously in an awake patient off cardiopulmonary bypass, this goal will not always be achievable.

\section{References} Surg. 2010;89:e48-50.

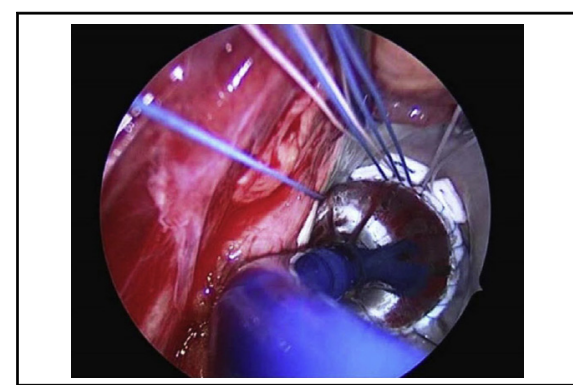

Transatrial valve implantation for severe mitral annular calcification.

\section{Central Message}

The development of transcatheter devices does not exclude their open application.

See Article page 132.

The authors are to be commended for successful application of new devices in an innovative manner that could potentially open options for otherwise high-risk or untreatable patients. The development of transcatheter devices does not exclude their open application. The use of a transcatheter device is not exclusively an open or shut case.

1. Praz F, Khalique OK, Lee R, Veeragandham R, Russell H, Guerrero M, et al Transatrial implantation of a transcatheter heart valve for severe mitral annular calcification. J Thorac Cardiovasc Surg. 2018;156:132-42.

2. Lee MS, Kozitza R, Mudrick D, Williams M, Lodge AJ, Harrison JK, et al. Intraoperative device closure of postinfarction ventricular septal defects. Ann Thorac

3. Neukamm C, Bjørnstad PG, Fischer G, Smevik B, Lindberg HL. A novel method of hybrid intraoperative catheter-based closure of ventricular septal defects using the Amplatzer® PDA occluder. Catheter Cardiovasc Interv. 2011;77:557-63. 